\title{
INNOVATIVE AND CROSS-SECTORAL CLUSTERS AS FACILITATORS OF VALUE ADDED CHAINS IN AGRICULTURE - SMART AGRO CLUSTERS IN ROMANIA
}

Cornelia MURARU-IONEL, National Institute of Research - Development for Machines and Installations Designed to Agriculture and Food Industry - INMA, Address:Ion Ionescu de la Brad Blv. No. 6, Sector 1 Bucharest, Romania; cornelia.muraru.ionel@gmail.com (corresponding author)

Sebastian Lucian MURARU, National Institute of Research - Development for Machines and Installations Designed to Agriculture and Food Industry - INMA, Ion Ionescu de la Brad Blv. No. 6, Sector 1 Bucharest, Romania; sebi_muraru@yahoo.com

Oana-Diana CRISTEA, National Institute of Research - Development for Machines and Installations Designed to Agriculture and Food Industry - INMA, Ion Ionescu de la Brad Blv. No. 6, Sector 1 Bucharest, Romania; diana10.cristea@gmail.com

Paula CONDRUZ, National Institute of Research - Development for Machines and Installations Designed to Agriculture and Food Industry - INMA,:Ion Ionescu de la Brad Blv. No. 6, Sector 1 Bucharest, Romania, paula.condruz91@ gmail.com

Clusters play an important role in driving competitiveness, innovation and jobs creation in the EU. Romania currently has successful clusters in various economic sectors and services, including 7 clusters in agro-food. Agriculture has been and remains the support of the human existence, which is an important pillar of the Romanian rural economy. The agro-food sector had oscillating evolutions in the post-accession period, mainly generated by the need to get in line with the EU requirements. Stimulating smart technology assimilation across all economic sectors including agro-food value chains, promoting enterprise growth and clusters 4.0 is critical to many EU Member States. Partnerships between countries, regions, cities and clusters are essential in the next industrial modernization process, based on innovation. Clusters 4.0 calls for development of a generation of advanced cluster policies to respond to these new industrial challenges by facilitating cross-sectoral value chains, fostering internationalization, stimulating inter-regional investment and accelerating entrepreneurship and skills in digital production, environmental production, circular economy, service innovation and creative economy. In order to be ready for the future, clusters must be geared towards creating a smart value chains, international cooperation and cross-sectoral partnerships. This research paper proposes a model as a tool for agro-clusters to become "smart", also this proposal providing information on the most important steps in the creation and development of smart agro-clusters. The used research methodology was based on analysis and synthesis of the information on the economic and social aspects of the development of the agro-food sector and of clusters in Romania. In conclusion, the authors of this paper wanted to emphasize the necessity of the development of smart agro-clusters for the future smart specialization of the regions.

Keywords: agro-clusters, innovation, smart specialization.

\section{INTRODUCTION}

The Romanian regional smart specialization strategies consider clusters as an important tool for increasing innovation in the region.

Clusters are generated by both business environment and research environment using the "bottom-up" or "topdown" procedure.

As a result of Romanian Cluster Mapping, done by the Ministry of Economy, responsible for Romanian cluster policy, in Romania there are 76 clusters in different development stages (emerging, mature), of which 47 are members of Romanian Cluster Association - CLUSTERO. 59 clusters received gold, silver or bronze label with different periods of validity by the European Secretariat for Cluster Analysis (ESCA). In the Agro-Food sector, 7 regional and cross-regional clusters are active and labelled with gold, silver and bronze. (Ministry of Economy \& Romanian Cluster Association, 2018).

Agriculture is a traditional branch of the Romanian economy. The contribution of agriculture, forestry and fisheries to the GDP is around 6\% of GDP above the EU Member States where it is around 1.7\%. Of the 23.8 million hectares of Romania, the agricultural area used on agricultural holdings is about 13.3 million hectares (55.9\%), out of which about 8.3 million hectares are arable land (National Institute of Statistics, 2018). The existence of a large number of small farms in parallel with the big farms shows the structural imbalance that influences the agriculture in our country and its competitiveness.

According to „Agriculture, forestry and fishery statistics, 2018 edition - EUROSTAT”, at the level of 2016, the agricultural labor force in the EU represents $4.2 \%$ of the total number of employees, while in Romania it represents $23 \%$ of the total number of employees in the country. The agricultural area is mostly owned by large holdings. However, the Romanian agriculture is a subsistence one. The rural economic development is closely linked to the existence of the 
appropriate transport infrastructure and the connection to utilities. An additional chance has the rural communities located in the vicinity of urban agglomerations.

The agro-food industry accounts for $27 \%$ of the total value of agricultural production. It provides over 180,000 jobs, about $11.6 \%$ of the total number of employees in the Romanian industry and $2.1 \%$ of the total Romanian labor force (National Institute of Statistics, 2018).

The Romanian agro-food industry is facing several challenges: demographics, scarcity of natural resources, climate change and food waste that are the same as those in other EU Member States. Future agriculture will use sophisticated technologies such as robots, temperature and moisture sensors, aerial images and GPS technology. These advanced devices and precision agriculture and robotic systems will allow farms to be more environmentally friendly. The structure of the land and its surface allow the application of Agriculture 4.0 in Romania to obtain significant results.

Agriculture 4.0 concept was implemented firstly by the specific Romanian agro-cluster members using the model described in this paper. The used research methodology was based on analysis and synthesis of the information on the economic and social aspects of the development of agriculture, the agro-food industry and of clusters in Romania (INTERREG Danube Transnational Program, 2019).

\section{INNOVATIVE CLUSTERS AS FACILITATORS OF VALUE ADDED CHAINS IN THE ROMANIAN AGRO- FOOD SECTOR}

Value chains are an increasingly complex approach and an useful tool to understand the challenges in the agriculture and food industry development in Romania.

Value chain length theory, developed by Dietzenbacher, Romeo, Bosma (Dietzenbacher, E., et. Al. "Using Average Propagation Lentgths to Identify Production Chains in the Andalusian Economy." Studies of Applied Economics 23 (2), 2005) and more recently by Fally (Fally, T. On the Fragmentation of Production in the US. Boulder: Universitiy of Colorado-Boulder, 2011) determines a country's position in global value chains by the average number of links in the production chain to the final consumer The length of value chains is a tool for better resource allocation and for reducing marginal production costs, so if a country's value chains towards the final product are shorter than the primary products, that nation is in a better position. downstream position (upstream) and upstream respectively. According to UNIDO (UNIDO. Industrial Value Chain Diagnostics: An Integrated Tool. Vienna: UNIDO, 2011), two diagnose analysis approaches of actual international value chains refer to development of clusters and respectively of system of innovation systems. The latest OECD study (De Backer, K., Miroudot, S. Mapping Global Value Chains in OECD Trade Policy Papers, No. 158. Paris: OECD Publishing, 2013) shows that Romania is one of the few countries that have migrated downstream, worsening its position, with a length of value chain in Romania of 1.9 links. On the whole, the fact that most countries have migrated upstream is explained by the general increase in the length of global value chains and the phenomenon of outsourcing, so that added value moves upstream to the intermediate products, which are then processed internally. In the international context characterized by an increase in protectionism in the post-crisis period, resulting in the "extension" of value chains in almost all major industrial powers (Germany, USA, China, Japan), Romania is anchored in European value chains, whose main engine is Germany. From this point of view, the New Industrial Revolution (Industry 4.0) will fundamentally reposition global value chains (The new Industrial Policy Document of Romania, Ministry of Economy, 2018).

The overall aim of the value chain analysis is to identify ways to improve the performance of a chain such that all actors are placed in a better position. In the process of elaborating the new industrial policy document of Romania, it was found that many value chains are transformed by digital technologies, based on EU best practices.

Clusters became facilitators of value chains creation in the Romanian agriculture and agro-food industry. Agroclusters are present in all regions of the country and involve strong actors in the region who want to increase innovation performances and restore value chains for the community wellbeing. The analysis demonstrated the existence of short value chains and lack of a better understanding of social and institutional settings in which the chain is operating. The ability of cluster members to innovate in order to capture greater value is an important goal of each agro-cluster.Clusters bring together different actors along the value chains and speed up innovative interactions between technologies, economic sectors, regions and policy tools. Romanian agro-clusters are both research driven and market driven. Trust among actors is a "strategic asset" that can increase performance of a value chain. The internationalization strategy is a main component of the development strategy of each cluster.

Cooperation within clusters in the agro-food field is focused on: smart farming and precision farming, organic agriculture, functional food, natural products, communication and information, technology and know-how transfer, development of human resources, new competences using infrastructure, promotion, breading and public relations, national and international cooperation and marketing.

One of the main objectives of the clusters is the collaboration and communication at national and international level. This objective can be achieved through cluster networks and associations. Thus, the agro-food clusters from Romania are members of various associations and cluster networks, like:

- CLUSTERO-Romanian Cluster Association;

- Networks in the projects Adriatic Danubian Clustering and ClusterPoliSEE;

- Consortium of clusters from Bucharest-Ilfov region;

- Network of clusters from South-East Europe and Balkans - Cluster House;

- National Network for Eco-Innovation - RE-IN; 
In this way clusters will have a lot of facilities, like:

- attracting investors;

- participation in European and national projects;

- increasing the visibility;

- exchange of experience and good practices;

- collaboration for news products, services and technologies;

- participation at national and international events;

- access to new markets;

- new partnerships;

- increasing the competences.

Agriculture 4.0 is a relatively new concept for the Romanian agro- clusters that understood to produce differently using new technologies (organic agriculture, bio-plastics, etc.), to use new technologies to bring food production to consumers, to increase efficiency in the food chain (e.g. vertical/urban farming), to incorporate cross industry technologies and applications (drone technology, internet of things, nano-technologies and 'precision agriculture, etc.).

The Romanian seven clusters active in the agro-food sector involve 168 companies with a total turnover of more than 2.786.844.635 euro for 2013-2017 period and 7.280 average employees / year, for the same period.

Following the implementation of the model proposed in this paper to become "smart", the following Romanian agro-clusters have improved year by year the economic indicators (turnover, profit, number of companies attracted, etc.) as is represented in figure no. 1:

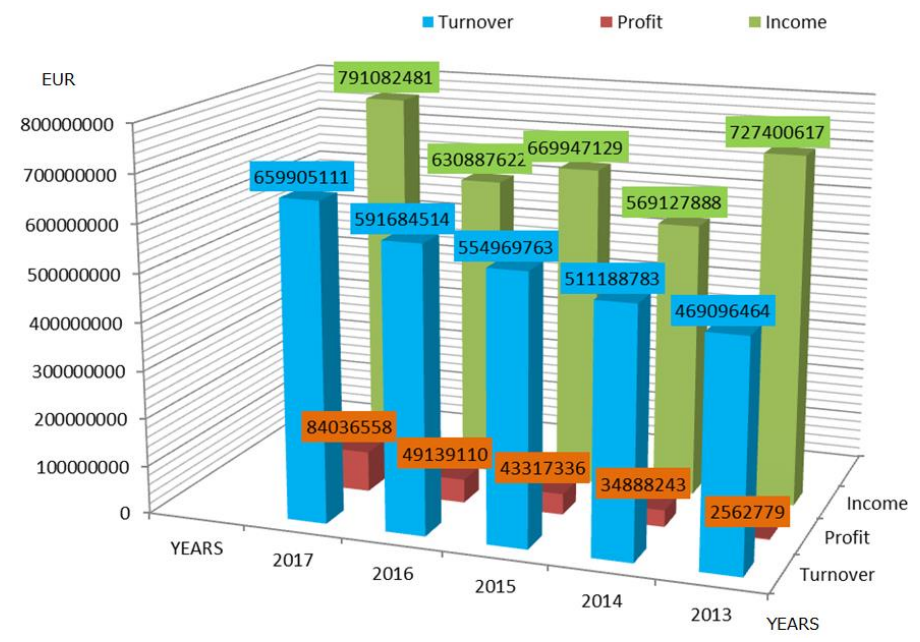

Figure 1. Annual closed accounting data of cluster companies, 2013-2017

\section{Agro Transylvania Cluster-North West Region - Regional cluster}

The mission of the cluster consists of supporting the development of the agro-industrial sector in the region and not only, through collaboration and cooperation between industrial environment, bussiness and research.

- Cluster members: 83 entitities including enterprises, universities, research institutes, public bodies and others;

- CLUSTERO member;

- It is registerd on European Cluster Collaboration Platform;

- ESCA gold lebel (AGRO Transilvania Cluster, 2019).

\section{Ind-Agro-Pol Competitiveness Pole - Innovative Cluster}

The IND-AGRO-POL is an innovation cluster in the agro-industry sector and the related sectors.

The mission is to stimulate the innovation and collaboration in the agro-industrial sector (technologies and technical equipment construction for agriculture and food industry) and in related sectors, in order to strengthen the competitiveness and sustainable development of these sectors, regional development and intelligent growth, sustainable and favourable to social inclusion.

- Cluster members: 122 entitities including SMEs, big enterprises, professional associations, catalysts, RDI institutes, public authorities, regional authorities, banking and universities from all Romanian regions, linked on the specific value chains;

- Domains: Agricultural Inputs and Services, Food Processing and Manufacturing, Agriculture Machinery and Technology Horticulture;

- Sectors: Bio-economy, Renewable energies, Environment and climate changes, Eco-technologies and advanced materials, Information technology and communications;

- CLUSTERO member;

- It is registerd on European Cluster Collaboration Platform;

- ESCA silver lebel (IND-AGRO-POL Cluster, 2019).

Agro Pro Oltenia-South West Oltenia Region- Regional cluster 
The mission of the cluster is to create a framework for dialogue between entities from diverse backgrounds (academic, private, public, civil society) with concerns in the agricultural sector, as well as the creation of a common brand in this field with the results in development of the whole South-West Oltenia region from the economic point of view and the social infrastructure.

- Cluster members: 26 entitities including SMEs, professional associations, RDI and public authorities;

- CLUSTERO member;

- It is registerd on European Cluster Collaboration Platform.

- ESCA bronze label (ADR S Oltenia, 2019).

Bio Concept Valea Prahovei - South Muntenia Region -Regional cluster

The cluster harmonizes and represents the interests of its members in order to increase the economic competitiveness and the creation of competences, sustainable development, internationalization, professional development of the managers and employees, the administration of a common database, the participation within the national and European networks and increasing the innovation potential of the enterprises.

- Cluster members: 22 entitities including SMEs, professional associations, catalysts, RDI entities and public authorities.

- Sectors:

- Organic agriculture and horticulture;

- Bio Medical;

- Bio Technology;

- Bio-economy;

- Tourism and cultural identity ( spa, medical, cultural, hiking);

- Food nutrients, cosmetics;

- Environmental protection and conservation;

- Renewable energies;

- Creative and cultural sectors;

- Social innovation (BIO Concept Valea Prahovei, 2019).

Ind Agro Vest -West Region - Regional cluster:

- Cluster members: 16 entitities including SMEs and large companies, universities, research and development institutes;

- member of CLUSTERO;

- It is registerd on European Cluster Collaboration Platform;

- ESCA bronze label.

The cluster is leader in manufacturing of agricultural machinery less harvesters and tractors for the domestic and foreign market.

Bio Danubius- South East Region - Regional cluster

The objective of the cluster is to increase economic competitiveness and create jobs, sustainable development of the South East Region, internationalization of members, professional development of managers and employees, administration of a common database, participation within national and European networks, increasing the innovation potential of the enterprises.

- Cluster members: 40 entities including SMEs, RDI, public administration, catalysts and others;

- Sectors:

- Organic agriculture;

- Pisciculture;

- Tourism;

- Logistics-transportation;

- Environmental protection and conservation;

- Renewable energies;

- Creative and cultural sectors;

- Social innovation.

- ESCA bronze label (BIO Danubius Cluster, 2019).

Agro Food Covasna -Romanian Central Region - Regional cluster

- Cluster members: 79 enterprises including SMSs, universities, research institutes, public bodies and others.

- Objectives:

- Developing a brand-based cluster policy;

- Common presence of the agricultural and agro-industrial products - regional branding;

- Partnerships, creation of supply chains and capitalization of the products;

- Professional training;

- Identification of the themes in RDI projects;

- Organizing events, taking over good practices and promoting the cluster;

- Participation in national, international projects.

- member of CLUSTERO; 
- ESCA silver label in 2019 (Agrofood Regional Cluster, 2019).

Romania loses its competitiveness at European and global level due to the modest degree of implementation at national level of digitization. Considering the characteristics of the Romanian agro-food sector and the need to support massive investments in innovation and digitization, the authors considered it necessary to conduct a pilot process in six steps having as main actors the clusters in agro-food labelled by ESCA.

\section{MODEL PROPOSAL FOR SMART AGRO-CLUSTERS IN ROMANIA}

The present model is a tool for implementing the ,smart”concept in agro-clusters in Romania and a novelty also for the digitization in the field. The experience of the EU Member States is different depending on the stage of cluster life cycle but also on the policies and strategies in the agro-food sector. Romania ranks 27th out of 28 EU Member States according to the European Commission'Digital Economic Index (DESI) - Romania's Country Report 2019. Despite the existence of many qualified ICT specialists, the general workforce in the agro-food sector does not have the digital skills and this has a negative impact on the economic activity. The pilot model was implemented successfully by the Romanian agro-food clusters with the support of CLUSTERO - The Romanian Cluster Association. The steps of this model are as follows:

Step 1: Raising awareness of "smart" concept among agro-clusters in Romania (the importance of Agriculture 4.0, Industry 4.0; Open Innovation 2.0) within specific events (conferences, seminars, workshops, fairs, working groups, etc.) and coordinating of training, mentoring and coaching programs for cluster and SMEs managers. In this process the authors follow the increase of cooperation between enterprises and universities, research and development institutes, local authorities, catalyst institutions, banks, civil society and of awareness on the benefits of belonging to a cluster by presenting the experience of exiting agro-clusters and of the evolution of enterprises within clusters.

Step 2: Identification of potential areas suitable for the development of smart agro-clusters in Romania (smart materials used in agro-industry; precision farming; functional food etc) in cooperation with the regional development agencies that have a database of enterprises and research entities, public institutions in the region.

Step 3: Identification of related smart specialization industries in Romania (bio-economy; organic agriculture, econano-technologies and advanced materials, etc.), located in each of the 8 development regions and which present opportunities for the development of smart agro-clusters. The cooperation with regional development agencies on revising the smart specialisation strategies further to an entrepreneurial discovery methodology is vital in this process.

Step 4: Development of policies and strategies for setting up and development of smart agro-clusters in cooperation with the specific ministries and regional development agencies and with the NGOs for alternative policies and strategies.

Step 5: Creating/developing of smart agro-clusters by establishing the founding cluster members and their involvement in the implementation process as well as of the cluster management organization. The existence of an agreement/protocol and of an implementation plan are important for establishment of the purpose, objectives and activities of the cluster in time horizons.

Step 6: Implementation of smart agro-clusters in Romania based on the experience of the successful clusters and of analysis of the performances of clusters made by CLUSTERO-Romanian Cluster Association. The authors follow the cluster development strategy based on objectives and performances, attracting of new members, internationalization and networking, training programs for cluster members, increasing of innovation, designing of projects of interest to cluster members as well as the capitalization of results.

This model can be improved by exchanging best practices with other similar clusters in the EU as part of projects of the next financing programs for the period 2021-2027 ( Horizon Europe, InvestEU11, Digital Europe etc).

\section{CONCLUSIONS}

The exchange of best practices on the governance of value added chains in the agro-food sector and of clusters is a main objective to be supported in the regional smart specialization strategies.

The model proposed for agro-clusters to become "smart" is designed in the context of the digitization process of agriculture and agro-food industry and it is intended to be an informative guide for cluster members on the most important steps for the creation and development of smart agro-clusters.

In conclusion, the smart agro-clusters bring major benefits in terms of the economic development and proper implementation of "smart specialization" concept.

Acknowledgements. This work was supported by a grant of the Romanian Research and Innovation Ministry, through Programme 1 - Development of the national research-development system, subprogram 1.2 - Institutional performance - Projects for financing excellence in RDI, contract no. 16 PFE and by "NUCLEU” Programme, developed with the support of the Romanian Research and Innovation Ministry, project no. PN 19100102.

\section{REFERENCES}

1. Agro Transylvania Cluster 2019. North West Region. available at http:www.agrocluster.ro (accesed on 31/07/2019).

2. Agrofood Regional Cluster.2019. AGROFOOD Regional Innovative Cluster. Available at http://www.agrofoodcovasna.ro (accessed on 31/07/2019).

3. ADR SUD VEST Oltenia. 2019.Agro Pro Oltenia. Available at http://4www.adroltenia.ro (accessed on 31/07/2019).

4. BIO Concept Valea Prahovei. 2019. Available at http://www.bioconceptvaleaprahovei.ro (accessed on 31/07/2019). 
5. IND AGRO WEST Association Sviluppo Insieme and Vince.Available at http://www.sviluppoinsiemesivince.ro (accessed on 31/07/2019).

6. Bio Danubius Cluster. 2019. Available at http://www.biodanubius.ro (accessed on 31/07/2019).

7. IND-AGRO-POL Cluster. 2019. IND-AGRO-POL pole of competitiveness.Available at http://www.inma.ro/indagropol/ (accessed on 31/07/2019).

8. Interreg Danube Transnational Program .2019.Romanian regions analysis of context and cluster innovation potential, Danube S3 Cluster project.

9. Ministry of Economy \& Romanian Cluster Association. 2018. Romanian Cluster Mapping.

10. Dietzenbacher E., Luna I. R., Bosma N. S. 2005. Using Average Propagation Lentgths to Identify Production Chains in the Andalusian Economy, Studies of Applied Economics, Vol. 23 (2), pp. 405-422.

11. Fally, T. 2011. On the Fragmentation of Production in the US. Boulder: Universitiy of Colorado-Boulder.

12. UNIDO. Industrial Value Chain Diagnostics: An Integrated Tool. Vienna: UNIDO, 2011.

13. De Backer K., Miroudot S. 2013. Mapping Global Value Chains in OECD Trade Policy Papers, No. 158. Paris: OECD Publishing,

14. The new Industrial Policy Document of Romania, Ministry of Economy, 2018.

15. National Institute of Statistics. 2018. Statistical Yearbook of Romania, pp. 500-524.

16. European Commission'Digital Economic Index (DESI)-Romania's Country Report 2019. 